\title{
Paideusis
}

\section{Blue Skies from Now On: A Reply to Barbara Thayer-Bacon's "Constructive Thinking"}

\section{Dennis Cato}

Volume 13, Number 2, 2000

URI: https://id.erudit.org/iderudit/1073016ar

DOI: https://doi.org/10.7202/1073016ar

See table of contents

Publisher(s)

Canadian Philosophy of Education Society

ISSN

0838-4517 (print)

1916-0348 (digital)

Explore this journal

Cite this document

Cato, D. (2000). Blue Skies from Now On: A Reply to Barbara Thayer-Bacon's "Constructive Thinking". Paideusis, 13(2), 73-76.

https://doi.org/10.7202/1073016ar viewed online.

https://apropos.erudit.org/en/users/policy-on-use/ 


\section{Blue skies from now on: A reply to Barbara Thayer-Bacon's "Constructive Thinking"}

Derinis Cato, Lachine, Québec

In an obvious sense, for blue skies to be an object of John's knowledge, John must know about blue skies. For John to be said to know anything at all, it is simply entailed in the meaning of the word that there is something for John to know, and in that sense there can be no separation between the knower and the known. However, if John lives deep in the rainforest or goes about with eyes habitually downcast in search of edibles, it is conceivable that he knows nothing of blue skies. There being no external referent for John's knowledge, it may even be said by John himself that he cannot have knowledge in this particular case. Alternatively, and for the same reason, John may reject the claim that blue skies exist or, more probably if he is trained in epistemology, assert that the claim that blue skies have independent ontological status is an empty concept.

For the "realist" who maintains that blue skies indeed constitute such an independent reality, John's rejection of their existence or the meaningfulness of the claim that they do independently of his knowledge of them merely reveals a deficiency in his cognitive stock, an unfortunate but not incorrigible situation. The realist might advise John to move out of the rainforest or look upwards now and then. For the "constructivist" however, for the one who maintains that there can be no sundering of the relation between knower and known, that all knowledge must necessarily be constructed by the knower, the deficiency lies not so much in John's cognitive stock but rather with the concept of a reality existing independently of his knowledge of it. Where all knowledge is constructed and where it is impossible to construct that which one doesn't know, the terms being interchangeable, the question of the independent ontological status of blue skies is meaningless. Moving from the rainforest or raising his upwards now and then will avail John nothing for he sees no reason to do.

By way of an attempt to show that "constructive thinking" as opposed to "critical thinking" is the proper epistemological basis for effective classroom practice, Barbara Thayer-Bacon shows herself to be firmly in the constructivist camp. To establish the primacy of constructivist thinking as the proper epistemological basis for classroom practice, however, Thayer-Bacon's two-step argument first presents a caricature of the practice of critical thinking in the classroom in comparison with its constructivist counterpart and, in a second step,

Paideusis 13: 2, 2000 
legislates the correctness of her constructivist philosophy in violation of its purported principles.

Where the teacher as critical thinker is portrayed in Thayer-Bacon's account as a thin-lipped rationalist concerned with students only as "disembodied minds" student bodies, for example, are seen by critical thinkers only as "distracters that can cause them to lose concentration"(p.32) - the teacher as constructive thinker, by contrast, is "dialogical". Her pedagogy is "relational" (students are viewed as "individuals-in-relation-with-others" (p.29)), it stresses "personal voice" ("without a personal voice, one cannot hope to contribute to knowing" (p.29)), and embodies the recognition of the student's "bodymind" ("...knowers are not disembodied minds, they are people whose minds are directly connected to their bodies, as one bodymind" (p.32)).

One wonders, however, why critical thinking teachers can't be "dialogical" too. Why can't they be "relational", "stressing personal voice", even while recognizing the student's "bodymind". Thayer-Bacon certainly gives no reasons why they can't be nor does she give evidence to show that they are not. It must just be written into what it means to be a "critical thinker". It must just be that ThayerBacon's insight that constructive thinking teachers were "dialogical" and critical thinking teachers were not was itself "constructed".

Having revealed how things stand in the classroom, Thayer-Bacon next sets her sights on establishing the correctness of that constructivist philosophy which will serve as the theoretical bulwark for her "dialogical" practice. The cardinal principle of the philosophy is the rejection of the Truth. "I may have more experiences, more education, and a more expanded, enlarged view as their teacher," Thayer-Bacon writes in respect to her students, "but I do not have the Truth" (p.36). As a consequence of lacking such Truth, Thayer-Bacon can only "negotiate" with her students. "I negotiate with my students", she reveals, "on criteria to help them understand that ultimately that is all any of us can do" (p.36). Where the known is necessarily connected to the knower, where my knowledge is mine and yours is yours and no one has the Truth, who would be so bold as to claim primacy?

As a matter of fact, Thayer-Bacon will. It turns out that some things just aren't negotiable, principal among which is Thayer-Bacon's possession of the Truth. "I reject realism (the assumption that knowledge is separate from knowers)", Thayer-Bacon proclaims, "and embrace James' radical empiricsm and Dewey's naturalism" (p35). That's one in the eye for the realists! Further, she can be found guilty of "subjectivism" only "if one assumes a subjective/objective distinction, which I do not assume, and which James has already refuted" (p.35). Those who did 
assume the subjective/objective distinction can just pack it in! It's the same for those who would accuse her of "naturalization". "When we begin to realize that we cannot ever get rid of ourselves, our personal voices, our subjectivity",Thayer-Bacon asserts, "then we begin to realize that it is impossible not to include ourselves in a description of knowledge, for the two cannot be separated" (p.35). Not much negotiation there! Those who have not yet begun to realize this can just go to the wall. Finally, Thayer-Bacon makes short work of those who would charge her with "relativism". The charge "only makes sense if one assumes there is a distinction between relativism and absolutism. This false distinction between relativism/ absolutism is based on the above assumption that knowers are divorced from what is known, that the world exists independently of us and what sense we make of it. This distinction has been shown to be false" (p.35). Well, there we are. ThayerBacon may not have the Truth, but she sure knows what's false!

It can only be that it was Thayer-Bacon, after all, who transcended her own partial and perspectival subjectivity to win through to a vision of the Truth, a vision in which it was vouchsafed to her, perhaps oddly, that no one could transcend their subjectivity, that all knowledge was necessarily perspectival and partial, and that no one could possess a vision of the Truth. It can only be that it was Thayer-Bacon, after all, who emerged from the rainforest, looked up, and glimpsed those blue skies!

\section{Notes}

1. See Barbara Thayer-Bacon, "Constructive Thinking versus Critical Thinking: A classroom comparison", Paideusis 13: 1, 2000, 21-39. 


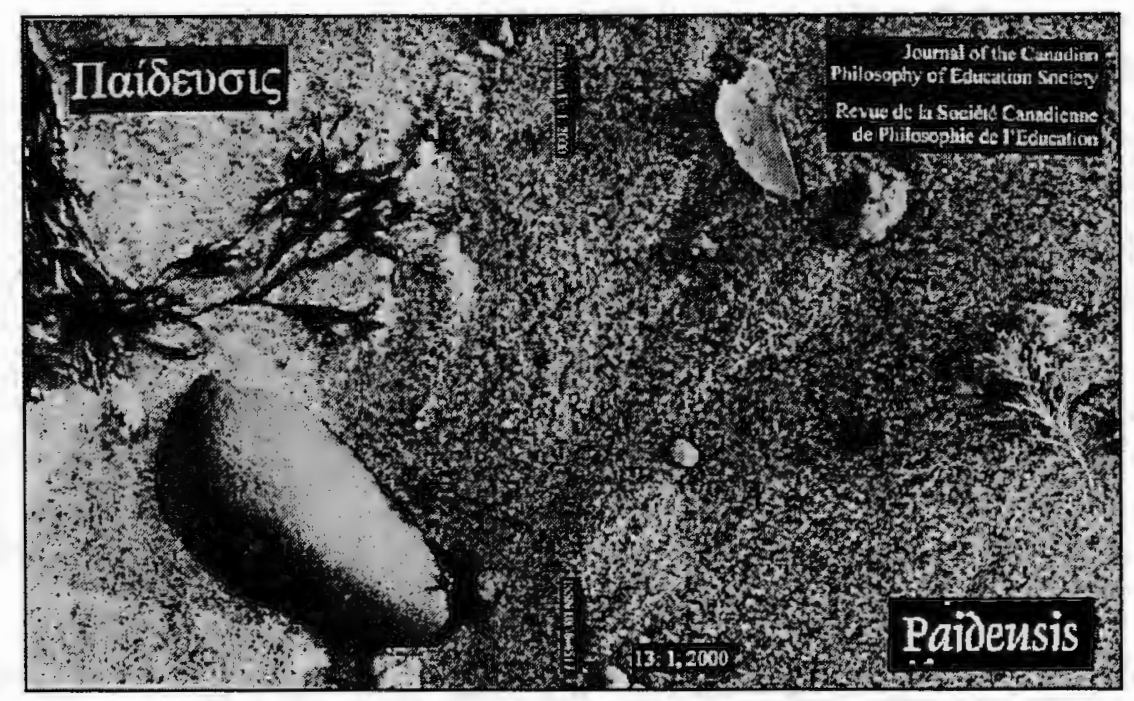

\section{Just a pretty picture? Or a philosophy of ed.?}

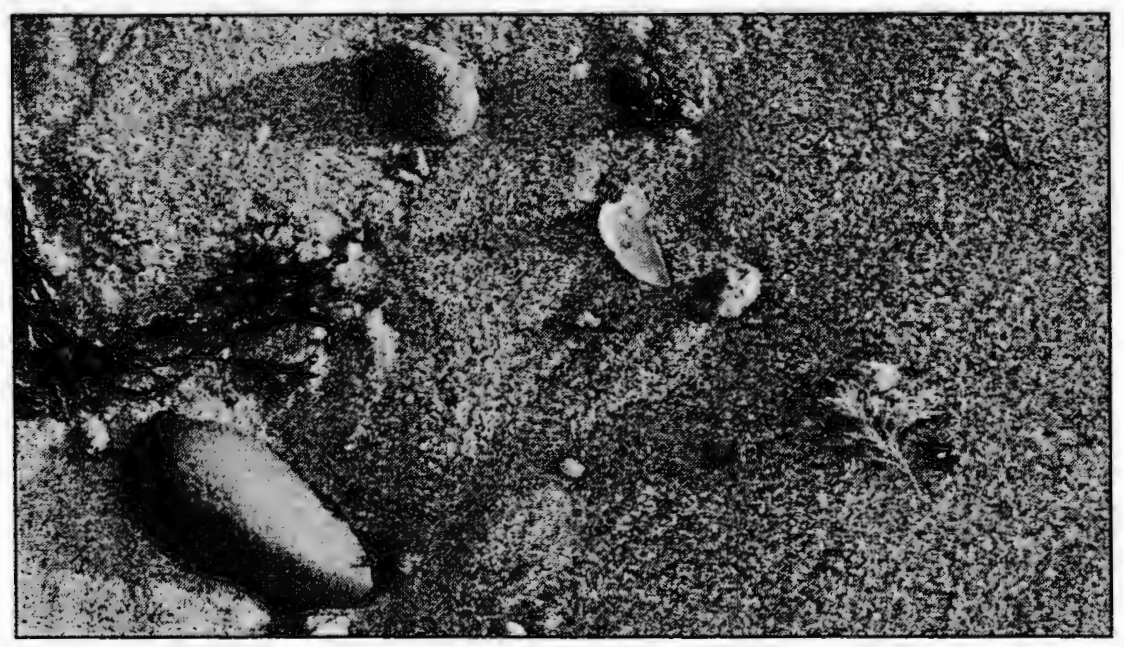

Mixed Media: B\&W photo-prints (14" x 8.5") and computer-generated graphic overlays.

- Michelle Forrest, 2000 